\title{
A DESAPROPRIAÇÃO DE BENS PÚBLICOS PELOS MUNICÍPIOS E O DESENVOLVIMENTO URBANO
}

\author{
Édson Carvalho*
}

RESUMO: A Constituição da República de 1988 reconheceu aos Municípios a mesma autonomia assegurada à União, aos Estados e ao Distrito Federal, a qual deve ser exercida nos limites da Constituição. Os Municípios são competentes para executar as políticas de desenvolvimento urbano, conforme as diretrizes fixadas em lei. Isso exige planejamento e a utilização de instrumento que conduzam ao cumprimento da determinação constitucional, incluindo a desapropriação de imóveis. De acordo com o art. $2^{\circ}, \S 2^{\circ}$, do Decreto-Lei ${ }^{\circ}$ 3.365/1941, os Municípios estão impedidos de desapropriar imóveis da União e dos Estados, surgindo a necessidade de investigar se tal previsão foi recepcionada pela Constitucional da República.

Palavras-chave: Desenvolvimento Urbano; Bens Públicos; Competência; Recepção Constitucional; Desapropriação.

\section{THE EXPROPRIATION OF GOVERNMENT REAL STATE BY MUNICIPALITIES AND URBAN DEVELOPMENT}

SUMMARY: The Brazilian Constitution of 1988 granted Municipalities, States, the Federal District and the Federal Government the same autonomy which must be exercised within the limits of the Constitution. Municipalities are competent to execute urban development policies, according to guidelines established by law. That demands planning and the use of an instrument which conducts to the execution of the constitutional determination, including real state expropriation. According to article I, paragraph 2 of the Decree Law 3.365/1941, Municipalities are not allowed to expropriate Federal and State real state, thus making it necessary to investigate whether this prediction is compatible with the Constitutional of the Republic.

Keywords: Urban Development; Government Real State; Competence; Constitutional Compatibility; Expropriation.

\footnotetext{
* Édson Carvalho, graduado pela Universidade do Vale do Itajaí. Especialista em Direito Público pela Escola da Magistratura Federal de Santa Catarina. Advogado com atuação na área de Direito Público. Professor na UNIVALI, nas cadeiras de Direito Administrativo e Direito Tributário. Mestrando em Ciências Jurídicas pela UNIVALI. edsoncarvalho@univali.br.
} 


\section{INTRODUÇÃO}

É nas cidades que o homem estabelece suas relações sociais, desenvolve atividade geradora de riquezas e fixa a sua moradia, necessitando da atuação do Poder Público para prover as suas necessidades em educação, saúde, lazer, moradia, segurança, infraestrutura, saneamento básico.

A ocupação desordenada do espaço urbano ou a existência de vazios causa problemas sociais e ambientais, havendo a necessidade de o Poder Público atuar de forma eficaz para impedir que esses problemas se configurem ou para reverter o quadro que se apresenta.

A Constituição da República estabeleceu em seu art. 182 os objetivos visados pela política de desenvolvimento urbano a ser executada pelos Municípios, destacando-se o pleno desenvolvimento das funções sociais das cidades e a garantia do bem-estar de seus habitantes.

Para cumprir os deveres constitucionais impostos ao Estado, o Poder Público utiliza seu patrimônio. O conjunto patrimonial do Estado está classificado em bens de uso comum do povo, bens de uso especial e bens dominicais, segundo a destinação dada aos mesmos. As duas primeiras categorias atendem interesses do povo ou da Administração, enquanto a terceira contempla bens que não têm emprego efetivo no atendimento das necessidades públicas, podendo se constituir em vazios urbanos que acarretam diversos problemas sociais.

O presente artigo tem por objetivo analisar a possibilidade de os Municípios desapropriarem imóveis desafetados pertencentes à União e aos Estados, como condição para a execução adequada de política de desenvolvimento urbano, diante da vedação contida no Decreto-Lei no 3.365/1941.

Para tanto, será analisada a classificação e as características dos bens públicos e a sua importância para o atendimento de interesses do povo ou da Administração, e também como se estabelece a sua afetação.

Em seguida, será analisada a determinação constitucional voltada para os Municípios, impondo-lhes o dever de criar políticas de desenvolvimento urbano e executá-las.

Também será analisada a formação do ordenamento jurídico decorrente do advento de nova ordem constitucional e o instituto da recepção de normas pré-constitucionais, objetivando estabelecer os pressupostos para se avaliar se a limitação imposta pelo Decreto-Lei $\mathrm{n}^{\circ}$ $3.365 / 1941$ encontra fundamento constitucional. 
Por fim, será analisada a possibilidade de os Municípios desapropriarem imóveis desafetados pertencentes à União e aos Estados, que estejam localizados em seu território, como condição para a execução adequada de política de desenvolvimento urbano.

Para o desenvolvimento deste trabalho foi realizada pesquisa bibliográfica e adotado o método de abordagem dedutivo.

\section{A DESAPROPRIAÇÃO DE BENS PÚbliCOS PELOS MUNICÍPIOS E O DESENVOLVIMENTO URBANO}

Nos termos da previsão constitucional contida no art. 182, compete aos Municípios executar a política de desenvolvimento urbano, conforme diretrizes gerais fixadas em Lei federal.

O Estatuto das Cidades, Lei federal $n^{\circ} 10.257 / 2001$, fixou as diretrizes gerais, cujas balizas normativas devem ser levadas em consideração pelos Municípios ao estabelecerem o Plano Diretor e os demais instrumentos aptos a viabilizarem a formulação e consequente execução da política de desenvolvimento urbano.

A desapropriação sanção, estabelecida no art. 182, $\S 4^{\circ}$, III, do texto constitucional, demonstra a percepção do constituinte com os percalços a serem enfrentados pelos Municípios, nas hipóteses em que os imóveis particulares não cumprem a função social da propriedade. Por meio da desapropriação sanção, a ocupação do solo urbano pode ser melhor gerenciada pelo Poder Público municipal, segundo os parâmetros fixados nos diversos diplomas legais.

O problema surge em relação aos imóveis não afetados pertencentes à União ou ao Estado em que o Município se localiza, que embaraçam a formulação e execução de política de desenvolvimento urbano definido pela municipalidade, por não estarem exercendo nenhuma função social ou atendendo a interesse público específico.

A desapropriação de bens públicos pelos Municípios encontra vedação expressa no Decreto-Lei ${ }^{\circ} 3.365 / 1941$, o que demanda a análise de sua recepção pelo texto constitucional, face à regra inscrita no art. 182 da Constituição da República.

Rev. de Direito Urbanístico, Cidade e Alteridade | e-ISSN: 2525-989X | Porto Alegre | v. 4 | n. 2 | p. 101 - 116 | Jul/Dez. 2018 


\subsection{Bens Públicos, suas Características e Funções}

Analisando o perfil histórico dos bens público, DI PIETRO (2015, p. 812) leciona que já havia referência a eles no Direito Romano. As res nullius diziam respeito às coisas extracommercium e englobavam as res communes (mares, portos, estuários, rios), as res publicae (terras, escravos), e as res universitatis (fórum, ruas, praças públicas) ${ }^{2}$.

Para CRETELLA JÚNIOR, as coletividades públicas são detentoras de bens materiais que integram o domínio. Tais bens, por sua vez, são divididos em duas classes: os que integram o domínio público e os do domínio privado.

Domínio público é o conjunto dos bens móveis e imóveis de que é detentora a Administração, afetados quer a seu próprio uso, quer ao uso direto ou indireto da coletividade, submetidos a regime jurídico de direito público derrogatório e exorbitante do direito comum (CRETELLA JÚNIOR, 2001, p. 805-805).

A partir dessa conceituação o autor destaca os característicos do domínio público, identificados como: a) conjunto de bens; b) pertencentes ao Poder Público; c) afetação à Administração ou à coletividade; e, d) regime jurídico de direito público.

Enquanto os bens que integram o domínio público estão submetidos ao regime jurídico de direito público, derrogatório do direito privado, outros bens pertencentes ao Estado, mas que não se encontram afetados à Administração ou à coletividade, submetem-se ao regime jurídico comum, o mesmo aplicável aos bens do domínio privado (CRETELLA JÚNIOR, 2002, p. 806).

O autor destaca que a expressão domínio público possui extensão menor do que a expressão bens públicos, pois há bens que ultrapassam aquele conceito, quando então são regidos pelo direito civil (CRETELLA JÚNIOR, 2002, p. 811).

A legislação brasileira, a partir do art. 66 do Código Civil de 1916, classificava os bens públicos em três categorias, a saber: a) bens de uso comum do povo; b) bens de uso especial; e, c) bens dominicais.

A Lei $n^{\circ}$ 10.406/2002 (Código Civil) contempla a mesma classificação:

Art. 99. São bens públicos:

I - os de uso comum do povo, tais como rios, mares, estradas, ruas e praças;

II - os de uso especial, tais como edifícios ou terrenos destinados a serviço ou estabelecimento da administração federal, estadual, territorial ou municipal, inclusive os de suas autarquias;

III - os dominicais, que constituem o patrimônio das pessoas jurídicas de direito público, como objeto de direito pessoal, ou real, de cada uma dessas entidades.

\footnotetext{
${ }^{2}$ Em seguida, a autora destaca que as res publicae pertenciam ao povo.
} 
Analisando o critério estabelecido pelo referido diploma legal, DI PIETRO (2015, p. 814-815) assevera que o critério utilizado para tal classificação foi o da destinação ou afetação dos bens, o que permite agrupá-los em duas categorias: de um lado os bens que integram o domínio público do Estado, abrangendo os de uso comum do povo e os de uso especial, e do outro os bens do domínio privado do Estado, abrangendo os bens dominicais.

Nos termos do art. 100 do Código Civil, "os bens públicos de uso comum do povo e os de uso especial são inalienáveis, enquanto conservarem a sua qualificação, na forma que a lei determinar". Disso resulta que enquanto estiverem afetados ${ }^{3}$, os bens públicos são insuscetíveis de ser objeto do comércio jurídico, porque de modo contrário o interesse público poderia estar seriamente comprometido.

A mudança de uma categoria para outra não exige a edição de lei, tampouco de ato administrativo versando sobre a questão. A destinação de um bem público ao atendimento de fins igualmente públicos é um fato administrativo e como tal deve ser investigado.

Nesse sentido, adequado o posicionamento de CARVALHO FILHO, para quem

[...] a afetação e a desafetação constituem fatos administrativos, ou seja, acontecimentos ocorridos na atividade administrativa independentemente da forma com que se apresentem. Embora alguns autores entendam a necessidade de haver ato administrativo para consumar-se a afetação ou a desafetação, não é realmente a melhor doutrina em nosso entender. $\mathrm{O}$ fato administrativo tanto pode ocorrer mediante a prática de ato administrativo formal, como através de fato jurídico de diversa natureza. Significa que, até mesmo tacitamente, é possível que determinada conduta administrativa produza a afetação ou a desafetação, bastando, para tanto, verificar-se no caso o real intento da Administração (CARVALHO FILHO, 2012, p. 1.149).

De fato, não é o ato formal emanado do Poder Público que estabelece a afetação, mas sim o seu efetivo uso comum ou especial.

Entender de modo diverso poderia acarretar graves inconvenientes para a Administração Pública. Imagine-se, por exemplo, que um prédio pertencente a determinado Município está sendo efetivamente utilizado para o funcionamento de uma creche mantida pelo referido ente, apesar de não ter sido editado nenhum ato formal afetando tal bem à consecução dessa finalidade.

Invocando o disposto no art. $2^{\circ}$, do Decreto-Lei $\mathrm{n}^{\mathrm{o}} 3.365 / 1941$, o Estado resolve desapropriar o referido imóvel para instalar ali uma Secretaria sua.

${ }^{3}$ Para MELLO (2007, p. 882) “Afetação é a preposição de um bem a um dado destino categorial de uso comum ou especial, assim como desafetação é a sua retirada do referido destino. Os bens dominicais são bens não afetados a qualquer destino público". Esse também é o entendimento de CARVALHO FILHO (2012, p. 1.149).

Rev. de Direito Urbanístico, Cidade e Alteridade | e-ISSN: 2525-989X | Porto Alegre | v. 4 | n. 2 | p. 101 - 116 | Jul/Dez. 2018 
Se a afetação se constituísse apenas após a edição de ato formal emanado do titular do domínio sobre o imóvel considerado, neste exemplo estaria seriamente comprometido o direito fundamental das crianças à educação infantil, além de caracterizar afronta ao estabelecido no art. 208, IV c/c art. 211, $\S 2^{\circ}$, do texto constitucional.

Ocorre que os bens de que é titular o Poder Público pode se mostrar insuficiente ou inadequado para a satisfação das necessidades públicas, havendo a necessidade de buscar no patrimônio privado os bens necessários para o cumprimento de seus deveres constitucionais e legais.

Para satisfazer as necessidades públicas o Poder Público pode desapropriar ${ }^{4}$ imóveis. Por meio da desapropriação o rol de bens públicos é ampliado na categoria bens de uso comum do povo ou na categoria bens de uso especial. Esse entendimento leva em consideração as razões que justificam a desapropriação, sempre fundada ou na utilidade pública ou no interesse social. Significa dizer que o bem privado, ao passar para o domínio público, estará afetado ao atendimento da necessidade que justificou a sua incorporação ao patrimônio do Estado.

\subsection{Desenvolvimento Urbano}

A Constituição da República delineia o marco normativo a partir do qual as políticas de desenvolvimento urbano devem ser definidas e implementadas. Tais normas possuem natureza jurídica diversa, ora estando definidas na forma de princípios, em outras passagens com a roupagem de regras.

Mas talvez o mais importante a se extrair dessas normas constitucionais relativas ao desenvolvimento urbano seja a sua íntima relação com a promoção dos direitos fundamentais plasmados em seu texto.

Seria simplista compreender que o desenvolvimento urbano tem por objetivo apenas ordenar a ocupação das áreas urbanas, a partir de uma leitura rasa dos art. 182 e 183 do texto constitucional.

Certamente que o objetivo a ser alcançado pelas políticas públicas voltadas para o desenvolvimento urbano tem seu locus normativo no caput do art. 182, segundo o qual o Poder

\footnotetext{
${ }^{4}$ CARVALHO FILHO (2012, p. 820) define a desapropriação nos seguintes termos: "Desapropriação é o procedimento de direito público pelo qual o Poder Público transfere para si a propriedade de terceiros, por razões de utilidade pública ou de interesse social, normalmente mediante o pagamento de indenização”.
}

Rev. de Direito Urbanístico, Cidade e Alteridade | e-ISSN: 2525-989X | Porto Alegre | v. 4 | n. 2 | p. 101 - 116 | Jul/Dez. 2018 
Público municipal, delimitado pelas diretrizes gerais fixadas pela União, deve buscar o "pleno desenvolvimento das funções sociais da cidade e garantir o bem-estar de seus habitantes".

Escrevendo sobre o direito ao desenvolvimento, GISI destaca que:

$[\ldots]$

A concepção do direito ao desenvolvimento envolve as noções de: livre determinação dos povos; direito à soberania sobre os recursos naturais; eliminação de violações massivas de direitos humanos; indivisibilidade e interdependência dos direitos humanos; paz e segurança internacionais; a pessoa humana como principal sujeito (participante e beneficiário) do desenvolvimento; igualdade de oportunidades tanto para as nações quanto para as pessoas e que os recursos obtidos do desarmamento sejam investidos no bem-estar das pessoas, especialmente do terceiro mundo; esforços para uma nova ordem econômica internacional. Define-se como "o direito de todas as pessoas humanas em todas as partes, e a humanidade como um todo, de realizar seu potencial, segundo Upendra Baxi e registrado por Lima (CLÈVE etall, 2014, p. 539540).

$[\ldots]$

Se o direito ao desenvolvimento está intimamente ligado à promoção de direitos fundamentais de diversos matizes, é possível afirmar com GISI que ele tem suporte também no preâmbulo do texto constitucional, no seu art. $3^{\circ}$ e nas disposições da ordem econômica e social, nas disposições que disciplinam a cidadania, a dignidade da pessoa humana, os valores sociais do trabalho e da livre-iniciativa, no pluralismo cultural e político, na construção de uma sociedade livre, justa e solidária, na busca pela erradicação da pobreza e da marginalização, na redução das desigualdades sociais e regionais dentre outros (CLÈVE etall, 2014, p. 540).

Percebe-se que o conceito de desenvolvimento aqui adotado não se restringe ao econômico, por ser muito restrito e insuficiente para explicar as diversas vertentes em que o desenvolvimento deve ocorrer para propiciar o bem-estar das pessoas.

Nesse sentido, para os fins deste artigo, deve-se entender o desenvolvimento enquanto direito em sua mais ampla acepção, de modo a abarcar, além do aspecto econômico, o social, o ambiental, o cultural, o urbano, sem excluir outras dimensões. Esse sentido amplo deve ser considerado quando se fala em desenvolvimento urbano, especialmente quando se tem em mira sua conexão com os direitos fundamentais.

Adverte GISI que,

$[\ldots]$

O desenvolvimento, descolado da perspectiva meramente econômica, sem naturalmente excluí-la, possibilita olhares em dimensões interessantes para o resgate ou construção de uma sociedade que propicie a seus indivíduos ou grupos integrantes autonomia e proteção jurídica suficiente para garantir a criação e a manutenção de formas de produzir e reproduzir em escalas individuais, familiares e comunitárias, sem ser solapado por um mercado autorregulável e suas gigantescas demandas para a satisfação de suas ilimitadas necessidades (CLÈVE etall, 2014, p. 538).

Rev. de Direito Urbanístico, Cidade e Alteridade | e-ISSN: 2525-989X | Porto Alegre | v. 4 | n. 2 | p. 101 - 116 | Jul/Dez. 2018 
$[\ldots]$

A Lei federal $\mathrm{n}^{\circ}$ 10.257/2001, regulamentando o art. 182 do texto constitucional, reproduziu aquela regra em seu art. $2^{\circ}$ e estabeleceu, em seguida, diversas diretrizes a serem observadas com o escopo de alcançar o objetivo constitucional de desenvolvimento urbano.

Tratando do assunto, MEDAUAR destaca que

$[\ldots]$

O caput do art. $2^{\circ}$ fixa como objetivo da política urbana o pleno desenvolvimento das funções sociais e da propriedade urbana. Nas funções sociais da cidade se entrevê a cidade como locus não somente geográfico e de mera reunião de pessoas, mas como o espaço destinado à habitação, ao trabalho, à circulação, ao lazer, à integração entre os seres humanos, ao crescimento educacional e cultural. Ao mencionar as funções sociais da propriedade urbana, com base certamente no art. $5^{\circ}$, XXIII, da Constituição Federal, o dispositivo ressalta o direcionamento da propriedade urbana a finalidades de interesse geral, com as quais há de se conformar ou conciliar o direito individual de propriedade, não mais dotado de caráter absoluto (MEDAUAR, 2004, p. 25-26).

$[\ldots]$

As cidades não devem se manter estagnadas. Ao contrário, como condição para o desenvolvimento humano e para a realização dos fins inerentes a sua condição, as cidades devem se desenvolver, incorporando tecnologias e inovações que permitam a todos desempenhar suas atividades, perseguir seus objetivos individuais e coletivos, se desenvolver intelectual e culturalmente enfim, viver plenamente suas vidas.

Atualmente muitas são as cidades espalhadas pelo mundo, em tamanhos diversos e estruturadas de forma diversificada. Mas o desenvolvimento das cidades a qualquer custo atende aos anseios de seus habitantes e significa o cumprimento das obrigações constitucionais pelo Poder Público?

LEITE destaca que

$[\ldots]$

A maioria das megacidades tem concentração de pobreza e graves problemas socioambientais decorrentes da falta de maciços investimentos em infraestrutura e saneamento. Sua importância na economia nacional e global é desproporcionalmente elevada. Segundo a Organização das Nações Unidas para a Educação, a Ciência e a Cultura (Unesco), no futuro teremos muitas megacidades que estarão localizadas em novos endereços - das 16 existentes em 1996, passarão a 25 em 2025, muitas delas fora dos países desenvolvidos (LEITE, 2012, p. 23). $[\ldots]$

Essa constatação demonstra a urgência no planejamento adequado das cidades, com o estabelecimento e implementação de políticas públicas aptas a viabilizar o desenvolvimento urbano e capazes de realizar os fins estabelecidos pelo texto constitucional e almejados pela população envolvida. 
A questão que se coloca é se imóvel pertencente ao Estado ou à União, localizado no território de Município, qualificado como bem dominical, necessário para a adequada implementação de política pública de desenvolvimento urbano, poderá ser desapropriado pelo Poder Público municipal. Esse questionamento tem, de um lado, a determinação constitucional no sentido de ser o Município o ente responsável pela execução de política urbana e, de outro, a regra do art. $2^{\circ}, \S 2^{\circ}$, do Decreto-lei $n^{\circ} 3.365 / 1941$, que impede os Municípios de desapropriarem imóveis da União e dos Estados.

Para responder adequadamente a este questionamento, será necessário avaliar se existe abertura constitucional que autorize a limitação da regra insculpida no seu art. 182, por ato normativo infraconstitucional.

\subsection{A Formação do Ordenamento Jurídico e a Recepção de Normas Pré-Constitucionais}

Para BOBBIO (2014, p. 55), fontes do direito "são aqueles fatos e aqueles atos dos quais o ordenamento jurídico faz depender a produção de normas jurídicas”, não interessando para uma teoria do ordenamento jurídico a enumeração de suas fontes, mas sim o fato de que ele próprio, além de regular condutas, regula a produção normativa, ou seja, estabelece os parâmetros que devem ser observados para a produção de normas jurídicas.

O ordenamento jurídico brasileiro, segundo o escólio de BOBBIO, é classificado como complexo $^{5}$, haja vista que a produção normativa não está centralizada em um único órgão estatal. Várias são as instituições das quais emanam regras jurídicas.

A complexidade das relações jurídicas, que demandam novas disciplinas normativas, torna inviável que o Congresso Nacional dê conta de disciplinar todos os casos de forma exauriente. Além das várias matérias que demandam a atenção do legislador, impende destacar que grande parte delas exige alto conhecimento técnico na sua disciplina normativa. Desta forma, o legislador ver-se-ia frente à necessidade de regular um caso com grandes minúcias e que exigiria, em breve tempo, revisão, haja vista que a velocidade dos avanços tecnológicos torna inadequadas as disciplinas legais muito rapidamente.

\footnotetext{
${ }^{5}$ A classificação em ordenamento jurídico simples e ordenamento jurídico complexo, leva em consideração a fonte da qual emana a norma jurídica. Se for uma só a produzir norma jurídica, estar-se-á frente a um ordenamento jurídico simples. Ao contrário, se várias forem as fontes produtoras, o ordenamento jurídico será classificado como complexo (BOBBIO, 2014, p. 56-57).
}

Rev. de Direito Urbanístico, Cidade e Alteridade | e-ISSN: 2525-989X | Porto Alegre | v. 4 | n. 2 | p. 101 - 116 | Jul/Dez. 2018 
Para a formação do ordenamento jurídico são utilizados dois expedientes: a recepção, que significa a consonância de normas produzidas sob a égide de constituição anterior com a atual disciplina constitucional e que, por isso, continua a produzir efeitos; e a delegação, que significa a atribuição de competência normativa a Poderes estatais diversos ou a órgãos inferiores (BOBBIO, 2014, p. 50). Para o atingimento dos fins visados neste artigo mostra-se importante a análise apenas do instituto da recepção.

Com o advento de uma nova constituição, as normas jurídicas produzidas sob a égide do texto constitucional revogado continuam produzindo efeitos sob a vigência do novo texto constitucional, desde que haja compatibilidade material entre o direito pré-constitucional e a Constituição que recém entrou em vigor (BARROSO, 2008, p. 171) ${ }^{6}$.

Para saber se uma norma produzida anteriormente ao texto constitucional em vigor foi recepcionada pela novel Constituição, deve-se proceder àquilo que STRECK (2013, p. 45) denomina de filtragem constitucional ${ }^{7}$, por meio da qual se apurará a existência de compatibilidade material.

Sendo materialmente compatível com o texto constitucional em vigor, o direito préconstitucional continua produzindo efeitos jurídicos válidos, mudando apenas o seu fundamento de validade, que deixa de ser a Constituição que vigia ao tempo em que ele foi editado e passa a ser a nova Constituição.

$\mathrm{O}$ art. $2^{\circ}, \S 2^{\circ}$, do Decreto-Lei $\mathrm{n}^{\circ} 3.365 / 1941$ deve passar por essa filtragem. Havendo compatibilidade material entre a disciplina legal e o texto constitucional, a vedação ali contida deverá ser respeitada. De modo contrário, será viável a desapropriação de bens públicos também pelos Municípios.

\subsection{A Desapropriação de Bens Públicos pelos Municípios para Execução de Política de Desenvolvimento Urbano}

Os Municípios ganharam nova configuração com a Constituição da República de 1988, que em seu art. $1^{\circ}$ coloca-os ao lado da União, dos Estados e do Distrito Federal. Consoante o ensinamento de MILARÉ (2011, p. 666), “essa norma expressa a aceitação dos Municípios

\footnotetext{
6 "Do ponto de vista formal, inexiste inconstitucionalidade superveniente. Do ângulo material, a lei anterior incompatível terá sido revogada" (BARROSO, 2008, p. 171).

7 "Além disso, o papel de filtragem constitucional, a ser realizado no plano da jurisdição constitucional, pode representar a revogação de toda a legislação anterior incompatível com o novo texto constitucional e sua principiologia [...]" (STRECK, 2013. P. 45).
}

Rev. de Direito Urbanístico, Cidade e Alteridade | e-ISSN: 2525-989X | Porto Alegre | v. 4 | n. 2 | p. 101 - 116 | Jul/Dez. 2018 
como parte integrante e inseparável da Federação brasileira, alçando, consequentemente", a mesma importância reconhecida aos demais entes políticos.

Diversas e importantes atribuições foram dirigidas aos Municípios pela Constituição, cabendo destacar a competência para executar a política de desenvolvimento urbano, nos termos do art. 30, VIII e 182, do texto constitucional.

O art. 182 da Constituição da República estabelece:

Art. 182. A política de desenvolvimento urbano, executada pelo Poder Público municipal, conforme diretrizes gerais fixadas em lei, tem por objetivo ordenar o pleno desenvolvimento das funções sociais da cidade e garantir o bem-estar de seus habitantes.

Esse dispositivo constitucional, que encerra norma de eficácia limitada ${ }^{8}$, foi regulamentado pela Lei federal $n^{\circ} 10.257 / 2001$, que estabeleceu diversas diretrizes a serem observadas com o escopo de alcançar o objetivo constitucional de desenvolvimento urbano.

Tratando do assunto, MEDAUAR destaca que

\section{$[\ldots]$}

$\mathrm{O}$ caput do art. $2^{\circ}$ fixa como objetivo da política urbana o pleno desenvolvimento das funções sociais e da propriedade urbana. Nas funções sociais da cidade se entrevê a cidade como locus não somente geográfico e de mera reunião de pessoas, mas como o espaço destinado à habitação, ao trabalho, à circulação, ao lazer, à integração entre os seres humanos, ao crescimento educacional e cultural. Ao mencionar as funções sociais da propriedade urbana, com base certamente no art. $5^{\circ}$, XXIII, da Constituição Federal, o dispositivo ressalta o direcionamento da propriedade urbana a finalidades de interesse geral, com as quais há de se conformar ou conciliar o direito individual de propriedade, não mais dotado de caráter absoluto (MEDAUAR, 2004, p. 25-26).

$[\ldots]$

É nas cidades que os valores humanos do trabalho e das relações sociais se desenvolvem e se fortalecem, realizando o primado da dignidade humana e favorecendo o respeito aos direitos fundamentais. Também é nas cidades que a riqueza é gerada, melhorando a qualidade de vida de seus habitantes e promovendo o desenvolvimento econômico nacional, o que traz grande responsabilidade aos Municípios, que ao executarem políticas de desenvolvimento urbano devem conciliar os diversos conflitos que podem surgir em decorrência de interesses os mais diversos.

\footnotetext{
${ }^{8}$ SILVA (1999, p. 83) leciona que a indicação, no texto constitucional, de norma a ser produzida pelo legislador ordinário, reveste-se de "prescrições constitucionais de eficácia limitada, pois não regulam direta e imediatamente a matéria referente às entidades e órgãos mencionados; o constituinte preferiu incumbir dessa tarefa o legislador ordinário $[\ldots] "$.
} 
A existência de imóveis desafetados pertencentes ao Estado ou à União, em território municipal, pode comprometer a adequada ocupação urbana e prejudicar a execução de política de desenvolvimento urbano, além de criar ambiente propício para a criminalidade.

Segundo LEITE,

\begin{abstract}
Nas últimas décadas, tem-se observado uma emergência comum às grandes metrópoles: os antigos espaços urbanos centrais estão perdendo boa parte de suas funções produtivas, tornando-se obsoletos e transformando-se em territórios disponíveis, oportunos. Trata-se dos chamados vazios urbanos, wastelands ou brownfields.

Do ponto de vista urbanístico, essas transformações resultaram em uma séria de problemas comuns que vêm afetando as nossas cidades hoje. O abandono das áreas centrais metropolitanas pelo setor industrial e a conseqüente degradação urbana de espaços com potencial tão evidente de desenvolvimento - afinal, dotados de preciosa infraestrutura e memória urbana - é face da mesma moeda que expõe a urbanização ilegal, porém real e incontrolável, de nossas periferias. As consequiências desse chamado espraiamento urbano são dramáticas em termos de total insustentabilidade ambiental, social, econômica e urbana (ocorre, invariavelmente, em áreas de proteção ambiental) (LEITE, 2012, p. 9).
\end{abstract}

Os vazios urbanos podem decorrer não apenas do abandono de áreas centrais pelo setor industrial. Também o Poder Público, proprietário de áreas centrais não afetadas, pode ser o responsável por essa triste realidade urbana.

Na região central de Florianópolis, por exemplo, a União é proprietária de uma área com $32 \mathrm{mil} \mathrm{m}$, que foi cedida ao município para a construção de um parque. O projeto do paisagista Roberto Burle Marx, de 1978, previa a revitalização da área e a adequada ocupação para fins comerciais e de lazer. Porém, o município permitiu a ocupação irregular de parcela dessa área, além de instalar no local um estacionamento para veículos da COMCAP (Companhia de Melhoramentos da Capital) (NDONLINE, 2018).

Com a alteração da destinação da área a União retomou o imóvel, que se transformou em um vazio urbano, ocupado por usuários de drogas e flanelinhas, gerando insegurança para os que transitam pelo local.

Essa realidade aponta para a necessidade de se criar políticas de desenvolvimento urbano que realmente cumpram a determinação constitucional contida no art. 182, além de exigir responsabilidade na sua efetivação.

Imóveis desafetados não serão adequadamente ocupados pelo Poder Público, porque isso representaria emprego desnecessário de recursos públicos. Portanto, tais bens são classificados como dominicais, os quais integram o patrimônio público, mas não estão sendo utilizados para o atendimento das necessidades administrativas ou da população. 
Pode-se afirmar, com esteio no art. $182, \S 2^{\circ}$, do texto constitucional, que essas áreas pertencentes ao Poder Público, mas que se submetem ao regime jurídico de direito privado, formam vazios urbanos não atendendo à função social da propriedade.

Apesar disso, as medidas previstas no $\S 4^{\circ}$, do mesmo art. 182 da Constituição da República, mostram-se inaplicáveis ao Poder Público. Com efeito, não é viável o Poder Público municipal impor à União ou ao Estado o parcelamento ou a edificação compulsórios, quer em virtude da relação horizontal existente entre os entes políticos a partir da disciplina constitucional, quer porque não teria como o Município substituir a União ou o Estado no exercício da competência discricionária de que são titulares, para afetar determinado bem.

Também não é cabível a cobrança do IPTU progressivo incidente sobre o imóvel pertencente à União ou ao Estado, em decorrência da imunidade tributária estabelecida no art. 150, VI, $a$, da Constituição da República, de cuja redação não é possível extrair a possibilidade de se tributar o patrimônio público não afetado.

A desapropriação sanção também não é cabível, por exigir como pressuposto a ineficácia das medidas anteriormente analisadas. Não sendo possível exigir o parcelamento ou edificação compulsórios, tampouco cobrar IPTU progressivo, não se pode afirmar que a União ou o Estado desatenderam as investidas anteriores, de modo a legitimar a medida extrema da desapropriação.

Para fins de execução de política de desenvolvimento urbano, resta a possibilidade de o Município desapropriar esses imóveis por utilidade pública, mormente com esteio no art. $5^{\circ}$, $i$, do Decreto-Lei ${ }^{\circ} 3.365 / 1941$, acrescentado pela Lei federal $n^{\circ} 9.785 / 1999$. Ocorre que esse diploma estabelece em seu art. $2^{\circ}, \S 2^{\circ}$ a impossibilidade de os municípios desapropriarem bens públicos pertencentes aos Estados ou à União, nos seguintes termos:

Art. $2^{\circ}$. Mediante declaração de utilidade pública, todos os bens poderão ser desapropriados, pela União, pelos Estados, Municípios, Distrito Federal e Territórios. [...]

$\S 2^{\circ}$ Os bens do domínio dos Estados, Municípios, Distrito Federal e Territórios poderão ser desapropriados pela União, e os dos Municípios pelos Estados, mas, em qualquer caso, ao ato deverá preceder autorização legislativa.

Tal previsão infraconstitucional limita as ações dos Municípios que, no exercício de competência constitucional, vêem-se impossibilitados de utilizarem áreas públicas desafetadas pertencentes ao Estado ou à União, não podendo aplicar as medidas do art. $182, \S 4^{\circ}$, da Constituição, disciplinados pela Lei federal $n^{\circ} 10.257 / 2001$, tampouco desapropriar referidos imóveis, diante da vedação legal. 
Ao submeter a vedação condita no Decreto-Lei $3.365 / 1941$ ao filtro de constitucionalidade, percebe-se que a limitação legal conflita diretamente com o texto constitucional, ao menos por duas razões.

A primeira delas diz respeito à inexistência de previsão constitucional no sentido de impedir que União, Estados e Municípios desapropriem bens uns dos outros, ou que estabeleça determinada hierarquia entre os referidos entes políticos.

No exercício de suas competências administrativas o ente político pode se encontrar diante da necessidade de desapropriar bens pertencentes aos outros entes políticos, sob pena de descumprir determinações constitucionais. Havendo determinação constitucional impondo o dever de agir, e vedação legal restringindo as ações do ente estatal, deve-se afastar esta para viabilizar aquela.

Isso não significa defender a possibilidade de desapropriação em toda e qualquer situação, de bens afetados ou não. Implicitamente há limites a serem observados, como, por exemplo, quando o bem considerado estiver destinado ao atendimento de uma necessidade pública ou ao atendimento de interesse da Administração, o que exige a análise do caso concreto.

A segunda razão diz respeito ao nivelamento entre a União, Estados, Distrito Federal e Municípios, realizado pela Constituição da República, em cujo art. 18 estabelece a autonomia dos entes políticos. Portanto, desde 1988 não há hierarquia entre os entes políticos.

Este posicionamento é defendido por ANDRADE:

Concluímos, portanto, que a autonomia recíproca e o equilíbrio federativo, que devem pautar o relacionamento entre as entidades federativas, não impedem o exercício de poder expropriatório entre elas, mas obrigam, isso sim, que, para o exercício legítimo desse poder, sejam observados alguns limites e condições (ANDRADE, 2006, p. 115). ${ }^{9}$

O plano diretor é o instrumento indispensável para que o Município cumpra a determinação constitucional de viabilizar o desenvolvimento das funções sociais da cidade. Do escólio de MILARÉ (2011, p. 670-671) extrai-se que o plano diretor deve considerar a cidade em sua totalidade, não apenas a área urbana, devendo-se atentar para aquelas "comunidades do Município que se encontram em piores condições de vida e mais carentes de infraestruturas”.

\footnotetext{
${ }^{9}$ ANDRADE (2006, p. 115) enumera as seguintes condições: subjetiva, segundo a qual o ente que realizar a desapropriação deverá estar exercendo competência própria; objetiva, que impede que os bens públicos atribuídos pela Constituição a determinado ente sejam objeto de desapropriação, o que parece ser bastante claro, porque a afetação se dá a partir do próprio texto constitucional; e finalística, que exige que a medida seja adotada para satisfazer interesses públicos de envergadura.
}

Rev. de Direito Urbanístico, Cidade e Alteridade | e-ISSN: 2525-989X | Porto Alegre | v. 4 | n. 2 | p. 101 - 116 | Jul/Dez. 2018 
Para a consecução da finalidade estabelecida em nível constitucional, o Município pode se deparar com a necessidade de desapropriar imóvel desafetado pertencente à União ou ao Estado, dando-lhe destinação consentânea com a função normalmente exercida por bem afetado, qual seja, o atendimento do interesse público.

A incompatibilidade material do art. $2^{\circ}, \S 2^{\circ}$, do Decreto-Lei $n^{\circ} 3.365 / 1941$, com o texto constitucional, permite apontar para sua não recepção pela nova ordem constitucional, possibilitando que os Municípios desapropriarem imóveis desafetados dos Estados e da União, por utilidade pública, quando necessários à execução de política de desenvolvimento urbano.

\section{CONSIDERAÇÕES FINAIS}

Os Municípios receberam diversas atribuições após a promulgação da Constituição da República de 1988, que reconheceu a eles autonomia idêntica à reservada à União e aos Estados. Dentre essas atribuições se destaca a responsabilidade pela definição e execução de políticas de desenvolvimento urbano, tendentes a promover o pleno desenvolvimento das funções sociais da cidade e a garantir o bem-estar de seus habitantes.

Para o desempenho de suas atividades materiais o Poder Público tem a sua disposição bens de diversas categorias, que podem estar afetados ou não ao atendimento das necessidades públicas ou da própria Administração.

A afetação dos bens públicos pode ocorrer por meio da própria Constituição, por meio de lei ou por ato administrativo. Todavia, a afetação é um fato da administração, o que exige a análise de cada caso para se apurar de forma adequada se determinado bem está ou não afetado ao atendimento de um interesse público.

Ocorre que no cumprimento de suas obrigações constitucionais e legais, os bens de que o Poder Público necessita podem não ser suficientes ou adequados à satisfação dos interesses que lhe compete tutelar, havendo a necessidade de se apropriar de bens alheios. Essa apropriação deve ocorrer nas hipóteses constitucional ou legalmente definidas, segundo um procedimento previamente estabelecido, que atualmente é disciplinado no Decreto-Lei $\mathrm{n}^{\circ}$ $3.365 / 1941$.

Esse diploma legal contém regra que impede os Municípios de desapropriarem bens de propriedade da União ou dos Estados, o que pode prejudicar a formulação de política de desenvolvimento urbano ou a sua execução.

Rev. de Direito Urbanístico, Cidade e Alteridade | e-ISSN: 2525-989X | Porto Alegre | v. 4 | n. 2 | p. 101 - 116 | Jul/Dez. 2018 
Confrontado o art. $2^{\circ}, \S 2^{\circ}$, do Decreto-Lei $n^{\circ} 3.365 / 1941$ com a previsão contida nos art. 18 e 182 da Constituição da República, percebe-se a incompatibilidade material daquela regra com o texto constitucional, acarretando a sua não recepção pela nova ordem constitucional estabelecida em 1988.

Dessa forma, observadas condições subjetiva, objetiva e finalística, é possível apontar para a possibilidade de os Municípios desapropriarem imóveis não afetados, pertencentes à União ou aos Estados, localizados em seu território, por utilidade pública, como condição para a formulação e execução de política pública de desenvolvimento urbano.

\section{REFERÊNCIAS}

ANDRADE, Letícia Queiroz de. Desapropriação de bens públicos (à luz do princípio federativo). São Paulo: Malheiros, 2006.

BARROSO, Luís Roberto. O controle de constitucionalidade no direito brasileiro. 3. ed. rev. e atual. São Paulo: Saraiva, 2008.

BOBBIO, Norberto. Teoria do ordenamento jurídico.trad. De Ari Marcelo Solon. São Paulo: EDIPRO, 2. ed., 2014.

CARVALHO FILHO, José dos Santos. Manual de direito administrativo. 26. ed. rev., apl. e atual. até 31.12.2012. São Paulo: Atlas, 2013.

CLÈVE, Clèmerson Merlin; PEREIRA, Ana Lucia Pretto (coordenadores). Direito constitucional brasileiro: constituições econômica e social. vol. III. São Paulo: RT, 2014.

DI PIETRO, Maria Sylvia Zanella. Direito administrativo. 28. ed. São Paulo: Atlas, 2015.

JÚNIOR, José Cretella. Direito administrativo brasileiro. Rio de Janeiro: Forense, 2002.

LEITE, Carlos; AWAD, Juliana diCesare. Cidades sustentáveis, cidades inteligentes: desenvolvimento sustentável num planeta urbano. Porto Alegre: Bookman, 2012.

MEDAUAR, Odete; ALMEIDA, Fernando Dias Menezes de. Estatuto da cidade: Lei 10.257, de 10.07.2001, comentários. 2. ed. rev., atual. eampl. São Paulo: RT, 2004.

MELLO, Celso Antônio Bandeira de. Curso de direito administrativo. 23. ed. rev. e atual. até a EC-53/2006. São Paulo: Malheiros, 2007.

MILARÉ, Milaré. Direito ambiental: a gestão ambiental em foco: doutrina, jurisprudência, glossário. 7. ed. rev., atual. erefom. São Paulo: RT, 2011.

SILVA, José Afonso da.Aplicabilidade das normas constitucionais. 3. ed., 3. triag., rev., atual. eampl. São Paulo: Malheiros, 1999.

STRECK, Lenio. Jurisdição constitucional e decisão jurídica. 3. ed. São Paulo: Editora Revista dos Tribunais, 2013.

Rev. de Direito Urbanístico, Cidade e Alteridade | e-ISSN: 2525-989X | Porto Alegre | v. 4 | n. 2 | p. 101 - 116 | Jul/Dez. 2018 